\title{
8 Public participation as an essentially contested concept \\ Insights from water \\ management in Turkey
}

Gül Özerol, Aysun Özen Tacer and Mine Islar

\subsection{Introduction}

Many countries undertake efforts towards participatory water management that consist of replacing top-down institutional structures with bottom-up and networked structures. These efforts can be explained by the instrumental and normative benefits expected from public participation, and the resulting promotion of 'public participation' by both international organizations and water scholars (see also Chapter 2 of this book). Debates around public participation indicate however that there are multiple views regarding the definitions and uses attributed to the concept. Gallie (1956) introduced the idea of an 'essentially contested concept' and identified the following five conditions that determine whether a concept is essentially contested:

- the concept denotes a valued achievement

- the achievement is internally complex although its worth is defined for the whole

- the achievement is ambiguous with different descriptions for different people

- the achievement is vague since its attribution can change contextually and temporally

- the users of the concept defend the way that they use it against the other users

In light of its multiple definitions and uses and general agreement with the above five conditions, public participation is considered to be an essentially contested concept. Several scholars have addressed the contested nature of public participation and the implications of this contestation. Day (1997) examines public participation in policy planning processes and identifies public participation as an essentially contested concept that reflects the nuances and difficulties of democracy and requires expertise even to grasp its complexity. Regarding public participation in water management, Sneddon and Fox (2007) touch upon the contestation of the concept. They 
examine a case in transboundary water management and observe that the multitude of national and international actors employ different meanings of public participation and use those meanings to pursue individual goals or to exert power over other actors. Taking a critical stance, Molle (2008) identifies public participation as a 'nirvana concept', meaning that, just like integrated water resources management (IWRM), public participation appears desirable and uncontroversial, whereas at the same time it conceals the politics of water management and can be exploited by certain groups for legitimizing their agendas. Molle further argues that the implementation of public participation relies on the essential roles of the state in empowering public members and of the experts in providing information, hence reflecting the power asymmetries instead of balancing them.

Thus, we can assert that public participation in water management often has a contested nature. However, the underlying mechanisms and the resulting implications of the contestation process in a particular time and space remain a research gap. These mechanisms and implications are particularly relevant in explaining the transfer of public participation to contexts with a history of non-participatory water management, since the contested nature of public participation can constitute an obstacle against effective transfer, i.e. the achievement of instrumental and/or normative benefits through introducing public participation. Accordingly, in this chapter we aim to improve the understanding about the contested nature of public participation by analysing the underlying mechanisms and the implications of contestation. In particular, we reflect on the following research questions:

- Why does the concept of public participation become contested in water management?

- What are the implications of the contested nature of public participation in water management on the effectiveness of its transfer to nonparticipatory settings?

The outline of the chapter is as follows. In Section 8.2, we describe how we conceptualize the contested nature of public participation. Then in Sections 8.3 and 8.4, we present our empirical findings from case studies in Turkey, where we examine the transfer of participatory approaches to the national framework of water management and to three cases at the local level. In Section 8.5, we discuss the similarities and differences of transfer to local cases. Finally, in Section 8.6, we revisit our research questions and draw on conclusions.

\subsection{Conceptualizing the contested nature of public participation}

Since the definitions and uses of a concept are used to indicate its contested nature, we choose to make use of a discourse analytic perspective in this 
chapter. Discourse analysis constitutes an appropriate approach as it gives the opportunity to understand what shapes a social reality through examining the text and the context (Phillips and Hardy, 2002). The text includes the written and verbal communicative messages, whereas the context refers to the circumstances within which the text is generated. Analysis of discourses can be particularly useful for revealing the mechanisms through which the phenomena in the environmental domain are socially constructed and contested (Hajer and Versteeg, 2005). Being a key social phenomenon of environmental decision-making, public participation can thus be effectively analysed from such a discourse analytic perspective. As Table 8.1 shows, we formulate three questions to analyse the public participation discourses in water management.

Answering the three questions in Table 8.1 reveals the discursive positions of actors regarding the meanings and uses that they attribute to public participation. The second column of the table includes discursive positions that the multiple actors can possibly hold depending on the actual empirical settings. The first question addresses the discourses about the scope of the participants, which relates to representativeness and equity of public participation. The scope of the participants usually consists of a subset of the public, since involving everyone is often infeasible or unrealistic under time, money and human constraints (Mostert, 2003; Creighton, 2005; Özerol and Newig, 2008). However, contestation can arise when some actors, who are advantaged in terms of power and access to resources, become increasingly mentioned as stakeholders. In such cases, disadvantaged

Table 8.1 Questions regarding discursive positions about public participation

\begin{tabular}{|c|c|}
\hline Questions & Possible discursive positions \\
\hline $\begin{array}{l}1 \text { Who is 'the } \\
\text { public'? }\end{array}$ & $\begin{array}{l}\text { - All individual and collective actors are potential/actual } \\
\text { participants. } \\
\text { - Representation is biased towards the dominant/ } \\
\text { advantaged actors. } \\
\text { - The scope of 'the public' is implicit and/or ambiguous. }\end{array}$ \\
\hline $\begin{array}{l}2 \text { What is 'the } \\
\text { participation'? }\end{array}$ & $\begin{array}{l}\text { - Participation is an element of decision-making processes. } \\
\text { - Participation is symbolic ('business-as-usual' prevails). } \\
\text { - The scope of 'the participation' is implicit and/or } \\
\text { ambiguous. }\end{array}$ \\
\hline $\begin{array}{l}3 \text { Why was public } \\
\text { participation } \\
\text { introduced? }\end{array}$ & $\begin{array}{l}\text { - Public participation is an instrument to improve policy } \\
\text { outcomes. } \\
\text { - Public participation is expected to contribute to the } \\
\text { functioning of democracy. } \\
\text { - Public participation is an obligation imposed by external } \\
\text { actors. } \\
\text { - The rationale behind public participation is implicit } \\
\text { and/or ambiguous. }\end{array}$ \\
\hline
\end{tabular}


actors such as women, smallholders and the poor are often excluded from the scope of participants as they lack the necessary power and resources. The second question relates to the discourses regarding the level or type of participation. In her highly cited paper, Arnstein (1969) identifies several types of participatory mechanisms as 'non-participation' or 'tokenism'. These types of participation imply that either participation does not take place at all or it remains symbolic by not affecting the decision-making processes. In all types of participation, the scope of participation can become contested when actors attribute divergent or ambiguous definitions to it and use those definitions to further their interests. Therefore having clear boundaries for both the 'public' and 'participation' can improve the effectiveness of the transfer of public participation (Bressers and Lulofs, 2010). Finally, the third question addresses the discourses about the normative and instrumental rationales behind the transfer of participation (Innes and Booher, 2004). Unless the discourses about the rationale of participation contradict each other, multiple discursive positions can be present.

According to the Contextual Interaction Theory, contextual factors influence policy implementation processes by influencing actor characteristics (see Chapter 3 of this book). As the context is a key element of discourses, we apply this premise of the Contextual Interaction Theory to analyse actors' discourses regarding public participation. Accordingly, we assume that the discursive positions of different actors result from their characteristics (cognitions, resources and motivations) and are influenced by the wider, structural and case-specific contextual factors. Although they can vary with empirical cases, these positions address whether there is disagreement, uncertainty or ambiguity regarding the definition and use of 'public participation' in a given case. If there are such positions, it can be inferred that public participation is contested. As we mentioned above, the contested nature of public participation constitutes an obstacle against its effectiveness. We further argue that the more contested public participation is, the more difficult it is to effectively transfer it. This argument relies on the idea that a high level of disagreement, uncertainty or ambiguity in discursive positions leads to a lower likelihood of achieving the benefits expected from public participation. The implications of the contested nature of public participation on its effective transfer can be unfolded by further investigating the discursive positions of different actors.

\subsection{Public participation and water management in Turkey}

Turkey is a relevant case to analyse the transfer of public participation to water management since many attempts are being made towards a transition from non-participatory to participatory management. Prior to the 1980s, Turkish public management in general, and water management in particular, was characterized by a top-down and centralist institutional 


\section{G. Özerol et al.}

structure (Kibaroglu and Baskan, 2011). Since then, however, the country has been undergoing fundamental changes, which include among others the introduction of participatory mechanisms through the involvement of non-governmental actors in the planning, development and management of water resources. These changes can be attributed to various drivers such as the negotiation process to become a European Union (EU) member, the World Bank supported liberalization of the water sector, and the ongoing debates about water, energy and food security under the pressures of economic growth, population rise and climate change (Kibaroglu et al., 2009).

Previous experiences with public participation in the broader sphere of environmental decision-making have been limited in Turkey, yet they are increasing. For instance, several recent official documents and legislation refer to public participation. The latest national development plan (SPO, 2006) pinpoints the importance of enhancing local decision-making capacity as well as knowledge sharing and partnerships between the public and private sector and non-governmental organizations (NGOs). The preparatory reports of the development plan, which are compiled by expert groups and NGO representatives, also mention public participation as a key element to incorporate into environmental decision-making (SPO, 2007a, 2007b). Along the same lines, the Environmental Law that was amended substantially in 2006 incorporates several environmental policy integration principles, including among others the participation of non-governmental actors in the decision-making processes. Another key legal document related to public participation in environmental decisionmaking is the Regulation on Environmental Impact Assessment (EIA), which was enacted in 1993 and revised three times as part of the EU harmonization process. Building on the EU EIA Directive, the regulation includes provisions regarding public consultations during the planning of large-scale infrastructure projects that can have significant environmental impact.

Despite the supportive outlook in policies and legislation, the fact that Turkey did not ratify the Aarhus Convention (UNECE, 1998) shows that access to information and public participation is lacking not only in water management, but also in all areas of environmental decision-making. Nevertheless, there are efforts to incorporate new participatory mechanisms and improve the implementation of the public participation processes. For instance, with support from the Dutch government and the European Commission, pilot projects have been implemented in western Turkey to establish the institutional background for the implementation of the EU Water Framework Directive, and public participation and knowledge dissemination have been identified as being among the most crucial topics for compliance with the requirements of the directive (Grontmij, 2005).

The agricultural sector has the highest share of national water use and agricultural water management has been substantially reformed since the 
1990s (Kibaroglu et al., 2009). With financial and technical assistance from the World Bank, the Directorate General of State Hydraulic Works (Devlet Su İsleri, hereafter DSI) has undertaken the so-called 'accelerated transfer programme', which was inspired by the Mexican model of irrigation management transfer (Molle, 2008). This programme led to the establishment of water user organizations (WUOs) that took over the responsibility of implementing 'participatory irrigation management'. Most of the WUOs in Turkey are irrigation associations or irrigation cooperatives, which are, in principle, responsible for surface water and groundwater, respectively (DSI, 2012). Although these two types of WUOs have legal and administrative differences, they are both structured around the idea of farmers' participation in irrigation management. This idea continues to be one of the key messages of DSI, which argues that farmers' awareness of irrigation and self-organization abilities enables them to internalize irrigation management, and thus ask for and contribute to infrastructure investments (DSI, 2011). The countrywide establishment of WUOs constitutes a substantial step towards increasing farmer participation and is considered a success by other countries and funding agencies (Vermillion, 1997; Merrey et al., 2007). However, several issues such as the capture of WUOs' top management by the local elite and the inadequate monitoring of WUOs' performance impede effective implementation (Kadirbeyoğlu, 2008; Kibaroglu et al., 2009; Özerol, 2013).

Similarly to the developments related to agricultural water management, hydropower development in Turkey has been under pressure to increase the involvement of non-governmental actors, particularly the private companies that came into play over the last decade (Kibaroglu et al., 2009). The current government has embarked on an effort to promote small-scale hydroelectric facilities. The number is massive, with over 1,600 of such facilities being planned for Turkey's rivers over the coming decades. With the legal reform in 2001, use rights to the rivers are granted for forty-nine years to private companies to build small-scale, run-of-theriver hydroelectric facilities. Such a transfer of rights from the state to the private sector led to considerable tensions over rivers. The participation of lay public members is one of the contested issues since many communities were not satisfied with the outcomes of participatory meetings during the EIA of hydropower projects. According to Scheumann et al. (2011), the public consultations that are part of the EIA procedure only receive interest due to the significance of the social impacts on the local communities and the resettlements that result from the hydropower projects.

The experiences of the last three decades show that the transitions taking place in agricultural water management and hydropower development are characterized by a top-down imposition of participatory mechanisms led by the successive governments and supportive international agencies. The provisions in the relevant planning and legislative documents adopt an 


\section{G. Özerol et al.}

inclusive and participatory discourse. In practice, however, the NGOs can only minimally contribute and the lay public members are totally excluded from decision-making processes (Kibaroglu et al., 2009).

\subsection{Case studies of public participation in Turkey's water management}

Turkey has seven subnational regions that differ in terms of geographical and climate conditions as well as cultural and ethnic backgrounds. To better understand how factors at the case-specific level influence public participation, we examine the following three cases:

1 South-Eastern Anatolian Region: the case of participatory irrigation management in the Harran Plain, where abundant surface water is transferred from the Euphrates River for irrigated agriculture.

2 Central Anatolian Region: the case of participatory irrigation management in the Konya Closed Basin, where scarce groundwater is extracted from wells for irrigated agriculture.

3 Black Sea Region: the case of public consultation in EIA during smallscale hydropower development in the eastern part of the region.

We selected these regional cases for their political and social relevance for water management in Turkey. These regions also fall into the geographic focus of our ongoing research regarding water management in Turkey. To collect the discursive data about public participation in these cases, we used three types of data sources, namely documents, interviews and direct observation. The documents include previously generated text in the form of legislation, official reports, and scientific reports and articles. Through interviews and direct observation, we generated data that did not exist in the documents, which are produced mainly by corporate actors such as central and local administration units, professional organizations and NGOs. The opinions of certain actors, such as the water users and the middle-level personnel of governmental organizations, are not directly reflected in most of the documents. Therefore, we conducted semi-structured interviews to elicit the perspectives of such actors about the public participation processes and we made direct observations during our visits to the case study sites. For each case, we first examined the discourses to reveal the definitions and uses that different actors attribute to public participation. Then we investigated whether, how and why these attributions were contested through examining the disagreements, uncertainties or ambiguities in the discursive positions of the actors involved. In the following subsections, we present the description of the cases, followed by the discourses that were uncovered regarding public participation. 


\section{Harran Plain}

Harran Plain is located in Sanliurfa, one of the nine provinces in the South-Eastern Anatolian Project (Güneydoğu Anadolu Projesi, hereafter GAP). GAP is a multi-sector regional development programme that has been operating since the 1980s. Extensive irrigation is practiced in the plain using the Euphrates River's waters, which are stored in the Atatürk Dam reservoir and transferred to the fields through the $26.2 \mathrm{~km}-\mathrm{long}$ Sanliurfa Tunnels. A large-scale canal system irrigates an area of around $1,500 \mathrm{~km}^{2}$ (Aküzüm et al., 1997). When the irrigation with water from the Euphrates started in 1995, the DSI stipulated the establishment of irrigation associations in the newly irrigated areas. Irrigation associations implement participatory irrigation management by operating and maintaining the irrigation canals, distributing water to the farmers and collecting the irrigation fee, which is intended to cover the expenses incurred by the WUOs. The DSI supports the irrigation associations through providing trainings, lending machinery and equipment, and giving technical advice. As the irrigated areas are expanded, new irrigation associations are established in the GAP region.

\section{Who is 'the public'?}

In 2005, irrigation associations acquired the legal status of local administration associations under the Ministry of Interior through the Local Administration Associations Law. This provision implied the involvement of local administrators, namely the heads of villages and the mayors of municipalities, as the natural members of the top management of the irrigation associations. The Irrigation Associations Law, which was specifically crafted for the irrigation associations and enacted in March 2011, redefines the legal status of the irrigation associations as public legal entities. The enactment of a specific law and the change in the legal status of the irrigation associations imply a retreat of local administrations away from the management of irrigation associations, and a re-regulation of the management structure of the irrigation associations through specialized legal provisions.

The Irrigation Associations Law also contains a provision about assigning the number of votes according to the size of the land owned or used by the members of the irrigation association and grants a maximum of five votes to the farmers that own or use larger areas of land. Such a provision favours the participation of large-scale farmers over the disadvantaged farmers, whereas there are no mechanisms to facilitate the participation of disadvantaged farmers. Harran Plain is one of the regions that will be affected the most from this provision since the land is unequally distributed and the landlords already have additional power in the management of irrigation associations. A smallholder farmer summarizes his views on being involved in management: 'You need to be aga [landlord] to manage things'. 
Although it is among the mandates of participatory irrigation management, it is difficult to argue that the establishment of irrigation associations in Harran Plain enabled the involvement of disadvantaged groups in the decision-making processes. On the contrary, the hierarchical tribe structure continues to shape the management of irrigation associations (Özerol, 2013).

\section{What is 'the participation'?}

Both the DSI and the irrigation associations focus on the participation of individual farmers, which mainly occurs through their payment of the irrigation fee each year and voting in the irrigation association elections every four years. When it comes to the social interactions of farmers both with the top management and the staff of irrigation associations, the persistence of tribal culture, which relies on strong ties among the members of large families, is substantial (Özerol, 2013). The informal relationships are exploited in order to get things done by any type of organization: 'If you want to be served by the government offices, you need uncles [relatives or friends to ask for help]'. The tribal culture also leads to the prioritization of kinship and friendship relations over official relationships. This creates an uncertainty as to how management processes work and obstructs the enforcement of sanctions on the individual farmers and the irrigation associations when they violate the rules of irrigation management.

Regarding the enforcement of sanctions, the positions of farmers and DSI are relevant. Among the farmers, a common opinion about the functioning of irrigation associations is that irrigation associations just distribute the water'. Many farmers also think that the irrigation associations waste the fees that they collect from the farmers. However, until the enactment of the Irrigation Associations Law, the irrigation associations were not accountable to farmers, since the farmers were not members of the associations. The legal status of irrigation associations has also been an issue for DSI, since it lacked the legal power to enforce sanctions against the irrigation associations that neglect the maintenance of irrigation and drainage canals. Being local administration associations, the irrigation associations were administratively and financially accountable to the Ministry of Interior, which lacked the technical capacity to monitor the administrative and financial performance of the irrigation associations. With the enactment of the Irrigation Associations Law, the individual farmers gained the right to become members of irrigation associations, and DSI became the main administrative and technical auditor of the associations. Thus, the law changes the legal background for the accountability of irrigation associations to farmers and DSI. However, the enforcement of provisions towards improving the monitoring of administrative and technical performance remains to be seen. 
Why was participation introduced?

The DSI has transferred the operation and management responsibility of almost all the irrigation schemes it constructed (DSI, 2012). In the preamble of the Irrigation Associations Law, the key rationale behind the transfer programme is expressed as

the need to decrease the public expenditure on the operation, maintenance and repair of irrigation infrastructure, to improve the quality and speed of services, and to increase the collection rate of irrigation fees through creating the sense of ownership of farmers regarding the irrigation facilities

Such expectations are valid in many transfer programmes implemented throughout the world (Vermillion, 1997). In the Turkish case, all actors highlight the realization of economic expectations. However, there are criticisms about the lack of ownership by the farmers, since the irrigation infrastructure is deteriorated in many areas, including the relatively new infrastructure in the Harran Plain. A related item on the agenda of all related governmental organizations is to train the farmers in better irrigation management practices. If training were crucial to improve farmers' capacity in irrigation management, the farmers should have been trained well before the irrigation management transfer (Merrey et al., 2007). However, this was not the case in Harran Plain, and farmers' training is still considered a 'to-do' after having practiced irrigated agriculture for more than a decade, and the 'blame-the-farmers' rhetoric of the governmental organizations remains valid.

According to the DSI officials, farmers are currently managing the irrigation systems themselves and irrigation associations have financial and administrative autonomy, which is considered as a big achievement of the irrigation management transfer. However, the farmers in Harran Plain disagree with this argument and continue to see the state as the ultimate decision maker and problem solver. Particularly, the smallholder and landless farmers have little faith in the capacity or willingness of irrigation associations to solve problems such as lack of canal maintenance and unequal distribution of water. On the other hand, many governmental and non-governmental actors consider the DSI as the 'dominant' and 'reputable' actor, both in teaching and imposing roles in the management of irrigation systems. This role of DSI constitutes an obstacle for entering into collaboration with other relevant actors, such as the Directorate General of Agrarian Reform, which carries out land consolidation and land distribution in many irrigated areas in Turkey including the Harran Plain. 


\section{Konya Closed Basin}

Konya Closed Basin is a large-size basin (over $50,000 \mathrm{~km}^{2}$ ) that encloses five provinces. The basin is a prominent agricultural area, where mainly irrigated and groundwater-dependent agriculture are practiced. Major agricultural products are water-thirsty plants such as sugar beet and maize, which are supported through price subsidies by the government. The on-farm irrigation method is primarily surface irrigation, whereas less than 5 per cent of the land is irrigated using the water-saving drip or sprinkle systems. The basin faces major water problems such as excessive water withdrawal and use, and the water users - especially the farmers in the region - bear the economic consequences.

The rate of groundwater withdrawal (over 4.5 billion $\mathrm{m}^{3}$ per annum) in the basin is higher than that of replenishment (around 2 billion $\mathrm{m}^{3}$ per annum), which causes a $c .3 \mathrm{~m}$ annual drop in the groundwater table. Excess withdrawal primarily originates from the illegal wells drilled by farmers in their fields. DSI discloses that as high as 70,000 out of $c .100,000$ wells are illegal (not licensed by the DSI). As the groundwater retreats deeper each year, farmers encounter higher energy costs for water withdrawal, which in turn harms their products' competitiveness in the market and the sustainability of their agricultural income. Farmers typically refer to energy costs as one of the highest and continually increasing items in their cost structure. Groundwater in this basin is pumped from wells as deep as $100 \mathrm{~m}$.

The environmentally unsustainable situation in the basin continues to attract the attention of NGOs who see farmers' irrigation habits and the irrigation infrastructure as the origins of the water problems. To help limit this they are running capacity-building and infrastructural projects in the area. Despite the ongoing efforts of NGOs, specifically the World Wide Fund for Nature (WWF) and the academic organizations in the region, there is still a lot to do to improve the sustainability of water resources in the basin.

\section{Who is 'the public'?}

Inhabitants of the basin are farmers who have similar preferences in terms of crop choice (sugar beet) and irrigation method (furrow irrigation). Several parties, including the local agricultural authority, the DSI, the agricultural engineering department of the local university, NGOs and the regional utility company, have expectations about farmers' behaviour, such as changing the way they practice agricultural activities. Their suggestions are centred on saving water by changing irrigation methods and crops. The public, often considered as being only the farmers and occasionally including the irrigation associations and cooperatives, is characterized as 'non-cooperative' because of their reluctance to follow suggestions related to water sustainability. Among the parties mentioned above, there is a 
common tendency to view the public as ignorant, and even unconscious about the requirements of their core business.

Similar to the Harran Plain case, irrigation associations manage the surface water and irrigation cooperatives manage the groundwater in Konya Closed Basin. How local authorities perceive irrigation associations and cooperatives varies and depends on their operations. Some irrigation associations and cooperatives are known for their historically embedded malpractices, which are often overlooked by the local authorities, mainly due to the lack of institutions and legislations that monitor and control the operations of these organizations. Nevertheless, there are some irrigation cooperatives known for their good practices in terms of the sustainability of the water and well-being of the community.

\section{What is 'the participation'?}

Farmers' participation in Konya Closed Basin is often used interchangeably with 'contribution' to the infrastructure costs and 'taking responsibility' for sustainability of water. The irrigation associations have been suffering from severe water loss in the open-top secondary and tertiary canals. The DSI proposed the renewal of the system with closed-section canals and covered half of the costs on behalf of the associations, provided credit with favourable terms for the remaining half and asked the associations to collect the credit from their members. In some associations, farmers were reluctant to pay the irrigation fee, both because their income is very limited and because they believed that the government should pay for this service upgrade. As one farmer stated: 'Everyone claims a part of my little income: the utility company, the irrigation association, the [agricultural production] cooperative... Do they want me to starve? It is I who should be supported'. The government regards these as operational costs to be borne by the farmer and thus does not sympathize with the previous types of statements. Similarly, irrigation associations are blamed for mismanagement by the farmers and by some other parties such as DSI and regional government agencies.

The responsibility for sustainable water use is a rather new demand that has been placed onto farmers. They are expected to follow suggestions such as shifting to drip irrigation, adjusting their crop selection for less water consuming types and not opening new irrigation wells. However, farmers see little incentive to follow these suggestions. An academic, experienced in some pilot projects in the region, puts it this way: 'It is hard to persuade them that they will get the same productivity with less water.'

Almost all parties agree that raising awareness among the farmers proved to be inefficient, and the best way to cooperate with them is through proper incentive and sanctioning mechanisms. Heavy sanctions however, will not always induce the desired cooperative behaviour. Regarding the continuously dropping groundwater table, opening new irrigation wells in 
the basin is forbidden yet farmers keep opening illegal wells in their farms. As the head of DSI regional office comments:

It is illegal, yet I understand them... They need water to survive and the existing wells are not sufficient. What we need to do at this point is legalize the existing illegal wells and regulating their use through some quotas.

\section{Why was participation introduced?}

Participation is often confined to 'contribution to costs' by several parties. Yet, there is consensus on the idea that participation is regarded as the foremost requirement of water sustainability. The DSI, academia and NGOs agree upon the same game-theoretic proposition:

If left alone, all farmers will act in their own interest and open new irrigation wells, spend more water than they need and deplete the groundwater faster. We need to convince them otherwise and make them aware of the greater good.

In the eyes of DSI, participation is also a means to engage farmers in the decisions:

When asked to contribute financially, farmers are better at adopting the new systems. That is why we ask for a 50 per cent contribution from the farmers to the closed canal system infrastructure. This way, they will be more inclined to protect the close canal system.

Although participation practices are open to debate, some benefits are generally recognized. Academia and NGOs who run capacity-building and awareness-raising projects create quite an interest among the nearby farmers. Financial gains are still regarded as the most important outcome of practices that are being promoted in these projects. A farmer comments on this situation:

Farmers in Altınekin [where a pilot project on drop irrigation is implemented by WWF] are getting the same crop as I do, but pay less for the water and electricity they consume to access to water. I want this project in my village, too.

\section{Eastern Black Sea Region}

The Eastern Black Sea Region has a basin area of $24,077 \mathrm{~km}^{2}$ and is one of the richest basins when it comes to hydropower potential in Turkey. The basin has increasingly become the site of private hydropower development 
after the legal reforms of 2001. Due to its geographical and topographical advantages (high precipitation level, steep valleys), the region is among the most preferred places for the run-of-river type hydropower facilities. The estimated contribution of this region to the small-scale hydroelectric potential of Turkey is around 16 per cent (Uzlu et al., 2011). As a result, at least 300 projects are licensed and in the process of construction. Despite its energy potential, the basin also hosts many species as well as 2.5 million people, many of whose livelihoods depend on these rivers.

This small-scale hydropower development is regulated by 'water-use right contracts' that are prepared by the DSI. Accordingly, water-use rights to produce electricity are granted to companies for only forty-nine years. Since these contracts allow the privatization of water-use rights, communities now have limited or no rights to use the river for other purposes such as their domestic and agricultural use. As emphasized in the contracts, the ultimate rights of rivers belong to the state, and private companies obtain user rights. However, the company is responsible for the construction, management, operation and security of facilities and the potential risks derived from the usage of rivers. Because rights and responsibilities over the use of rivers are transferred to the private entities, there are serious uprisings from the rural communities in the region regarding their exclusion both in the current legal framework and in the decision-making processes.

\section{Who is 'the public'?}

Stakeholders from the public and the private sector can participate in the decision-making process through the EIA notification meetings. According to the Ministry of Environment, the transparent and democratic participation of different stakeholders is a necessary condition in the EIA process, since it is a process for finding out and preventing the future social and environmental implications of development programmes (Ahmad and Wood, 2002). The term 'public' is used to allow everybody to participate in the EIA legislation of 2008 (Scheumann et al., 2011). The private sector and affected communities have various views on the effectiveness of EIA meetings. Some of the locals from the region argue that meetings are far from being inclusive and democratic in practice. The majority of the communities do not participate in these meetings because they believe their views are being ignored and undermined. Private sector are willing to organize these meetings however some perceived them as loss of time and money.

\section{What is 'the participation'?}

The EIA process and thus the participation of the public only enter the project processes at the later stages of development (Scheumann et al., 2011). As a part of this process, EIA meetings are designed for consultation 
and sharing of information but the outcomes barely influence the decision making. Especially in the case of the Eastern Black Sea Region, public participation is very limited due to the high level of distrust between the local people and private companies. Some villagers choose not to recognize the process because they feel alienated from the process. Local knowledge and values are not recognized and excluded from the decision-making process.

Social and environmental concerns led to the mobilization of a powerful opposition towards hydroelectricity projects in the region. Apart from the activist groups in the Mediterranean Region (southern Turkey), such as Save Alakir Network and Yuvarlakcay Protection Platform, many other activist groups from the Black Sea region like Karadeniz Resurrection, Brotherhood of Rivers Platform and Ikizdere Association protest against hydropower projects during the EIA meetings. In many of these cases, nonparticipation has also become a position since some groups argue that participation would imply an indirect support of the process.

\section{Why was participation introduced?}

The international regulations and EU approximation process have influenced the EIA processes in Turkey. Recent changes in the EIA regulation have put more emphasis on public participation. Accordingly, stakeholders have to be informed and consulted about projects during the planning process. However, there is no consensus on the rationale behind introducing public participation into the planning of hydropower projects. According to the Ministry of Environment and Urbanization, public participation is necessary to build trust between communities and project owners and to provide a more transparent process by influencing the EIA process before projects are approved. This position is in line with the argument that the inclusion of public opinions in the EIA can lead to the development of a sense of ownership and reduce conflict (Shepherd and Bowler, 1997). However, a DSI official explains: 'The state is the ultimate owner of these rivers, we can consult people but at the end we are making the final decision'.

Although controversial in terms of inclusiveness, EIA notification meetings are the only platform bringing the public and the private sectors together. Through these meetings, people get information and express their opinions about the projects. However, due to the distrust between stakeholders, most often these meetings do not create a platform for a dialogue. On one hand, the majority of the private sector perceives EIA notification meetings as ineffective and time-consuming and, thus, not cost effective. On the other hand, some villagers perceived that the EIAs 'serve for the advertisement of their company'.

In the Eastern Black Sea Region, the active resistance groups against hydropower projects perceive EIA meetings as a mechanism that perpetuates 
the privatized water development regardless of the opposite views of the local people. However, some companies do recognize the importance of people's consent as we see in the Yuvarlakcay case in south-western Turkey, where a company has withdrawn its project as a result of the local resistance (Islar, 2010).

\subsection{Discussion: the contested nature and the transfer of public participation}

The analysis of discursive positions in three cases of public participation in Turkish water management reveals both similarities and differences regarding the contested nature of public participation. These similarities and differences can be attributed to various contextual factors as well as the characteristics of the actors.

Constituting typical examples of participatory irrigation management, the Harran Plain and the Konya Closed Basin cases provide insights about the interactions among the water users (individual farmers and WUOs) and the DSI. The discursive disagreements and differences among the water users and the DSI can be attributed to the imposition of the participatory approach on farmers without making sure that the farmers possess the required individual and organizational capacities for irrigation management so that they could share similar meanings of 'participation'. Furthermore, the scope of the 'public' is often limited to the local elite and the powerful farmers that have easier access to physical and financial resources. This power asymmetry is, in most situations, taken for granted by both the farmers and the DSI although it implies an 'elite capture', which can influence the decisions and inhibit the enforcement of sanctions (Kadirbeyoğlu and Özertan, 2011).

In the Eastern Black Sea Region case, participatory mechanisms are incorporated into the processes of hydropower planning. This case complements the other cases in terms of both the sectoral use of water resources and the phase of water management. Similar to the other cases, public participation is contested due to the divergent uses attributed to 'participation'. While the DSI and the private sector perceive the involvement of the public as a way to share information and consultation, local communities demand a more active role in the decision-making process. The Eastern Black Sea Region differs from the other two cases in two aspects. First, the affected local communities mobilize against the mechanisms that exclude their effective participation and, thus, aim to extend the scope of 'public'. Second, the role of DSI is less prominent in the participatory process since the risks and responsibilities of hydropower development are partly transferred to private actors (the companies taking over the use right of water resources). Nevertheless, in all the cases, the DSI holds the property rights for water. This fact positions the DSI as a prominent actor in the governance system as well as the ultimate decision-maker. The 


\section{G. Özerol et al.}

scope and the forms of participation by other parties, including public members and private actors, are shaped by the discourse that the DSI leads.

The contextual factors and the characteristics of actors influence the implications of the contested nature of public participation. The longstanding hierarchical structure in the Harran Plain manifests itself in all types of decision-making processes and limits the scope of the public to a privileged group. Furthermore, the lack of previous experience in irrigation management and the abrupt devolution of responsibility to the newly established irrigation associations are key determinants of the ongoing discourse on the incapability of farmers and their organizations in really participating in participatory irrigation management. Similarly, in the Konya Closed Basin case, actors' capacity play a prominent role in the way participation is interpreted and practised. References related to the incapability of farmers were often heard, which might explain why the discursive positions about participation are confined to contributing to costs and following the suggestions provided by the more capable actors, neither of which is a genuine form of participation. Resistance movements in the Eastern Black Sea Region case show that effective and inclusive participation is a necessary condition for both the future of hydropower development projects and social and political sustainability. Many projects cannot even be constructed due to the active resistance that eventually requires additional money, labour and time from the private companies. According to a lawyer from the Turkish Water Assembly, around 100 (almost half of the total proposed) projects are on hold due to court decisions (Y. Okumusoglu, personal communication, 2012).

\subsection{Conclusions}

In this chapter, we elaborated on the underlying mechanisms of the contested nature of public participation in water management and the implications of this contested nature on its transfer to non-participatory settings. Our empirical findings indicate that public participation becomes contested when actors with divergent characteristics attribute different definitions and uses to the concept. Combined with the influence of contextual factors, these divergent characteristics lead to several implications about the transfer of public participation to top-down and hierarchical water management settings. The immaturity regarding the adoption of participatory mechanisms in the broader arenas of environmental decisionmaking are also reflected in the water sector.

At the case-specific level, the low degree of individual and institutional capacity to engage proactively in the decision-making processes constitutes an obstacle in clarifying and expanding the boundaries of public participation. Despite the possibility of involving a broader scope of participants in multiple phases of decision-making processes, the more powerful actors continue to shape the dominant definition of public 
participation. Therefore, introducing participatory mechanisms that have been developed by external actors such as the EU and the World Bank remains insufficient for overcoming the power asymmetries and hierarchical structures at the local level.

The effectiveness of the transfer of participatory mechanisms to topdown and hierarchical water management settings can be improved in several ways. Regarding the implementation of participatory irrigation management, ensuring the involvement of disadvantaged farmers, primarily the landless and smallholder farmers, is of utmost importance. Furthermore, when the managerial and financial performance of WUOs are in question, the monitoring and evaluation by third-party (or independent) organizations can be useful to change the perception of farmers and other actors about the functioning of the WUOs. For the participatory planning of hydropower development, an independent stakeholder advisory group, which can voice local concerns, provide local knowledge, help to identify key issues and facilitate cooperation between different groups, can contribute to the public participation processes.

\section{References}

Ahmad, B. and Wood, C. (2002) 'A comparative evaluation of the EIA systems in Egypt, Turkey and Tunisia', Environmental Impact Assessment Review, vol. 22, no. 3, pp. 213-234.

Aküzüm, T., Kodal, S. and Çakmak, B. (1997) 'Irrigation management in GAP', Water Resources Development, vol. 13, no. 4, pp. 547-560.

Arnstein, S.R. (1969) 'A ladder of citizen participation', Journal of the American Institute of Planners, vol. 35, no. 4, pp. 216-224.

Bressers, H. and Lulofs, K. (eds) (2010) Governance and Complexity in Water Management: Creating Cooperation through Boundary Spanning Strategies, Edward Elgar, Cheltenham/Northampton, MA.

Creighton, J.L. (2005) 'What water managers need to know about public participation: one US practitioner's perspective', Water Policy, vol. 7, no. 3, pp. 269-278.

Day, D. (1997) 'Citizen participation in the planning process: An essentially contested concept?', Journal of Planning Literature, vol. 11, no. 3, pp. 421-434.

DSI (Devlet Su İşleri) (2011) Faaliyet Raporu 2010 (Annual Report 2010), DSI, Ankara.

DSI (Devlet Su İşleri) (2012) 'Hizmet alanları: tarım (Service fields: agriculture)', online, available at: www.dsi.gov.tr/hizmet-alanlari/tarim, accessed 5 November 2012.

Gallie, W.B. (1956) 'Essentially contested concepts', Proceedings of the Aristotelian Society New Series, vol. 56, pp. 167-198.

Grontmij (2005) Draft River Basin Management Plan Büyük Menderes and Gediz, Implementation of the Water Framework Directive in Turkey, Final Report, Grontmij Consulting Engineers, Houten.

Hajer, M. and Versteeg, W. (2005) 'A decade of discourse analysis of environmental politics: Achievements, challenges, perspectives', Journal of Environmental Policy and Planning, vol. 7, no. 3, pp. 175-184. 
Innes, J.E. and Booher, D.E. (2004) 'Reframing public participation: Strategies for the 21st century', Planning Theory and Practice, vol. 5, no. 4, pp. 419-436.

Islar, M. (2010) 'Privatized rivers of Turkey: The case of Yuvarlakcay', paper presented at the Berlin Conference on Human Dimensions of Global Environmental Change, 8-9 October 2010, Berlin.

Kadirbeyoğlu, Z. (2008) 'Decentralization and democratization: The case of water user associations in Turkey', PhD thesis, McGill University, Montreal.

Kadirbeyoğlu, Z. and Özertan, G. (2011) 'Users' perceptions of water user associations: Evidence from three cases in Turkey', Boğaziçi University Department of Economics, Working Paper 2011-1, pp. 1-29.

Kibaroglu, A. and Baskan, A. (2011), 'Turkey's water policy framework', in A. Kibaroglu, W. Scheumann and A. Kramer (eds) Turkey's Water Policy: National Frameworks and International Cooperation, Springer, Heidelberg/Dordrecht/ London/New York.

Kibaroglu, A., Baskan, A. and Alp, S. (2009) 'Neo-Liberal transitions in hydropower and irrigation water management in Turkey: Main actors and opposition groups', in D. Huitema and S. Meijerink (eds) Water Policy Entrepreneurs: A Research Companion to Water Transitions Around the Globe, Edward Elgar, Cheltenham.

Merrey, D.J., Meinzen-Dick, R. and Mollinga, P. (2007) 'Policy and institutional reform: The art of the possible', in D. Molden (ed.) Water for Food - Water for Life, Comprehensive Assessment of Water Management in Agriculture, EarthScan, London.

Molle, F. (2008) 'Nirvana concepts, narratives and policy models: Insights from the water sector', Water Alternatives, vol. 1, no. 1, pp. 131-156.

Mostert, E. (2003) 'The challenge of public participation', Water Policy, vol. 5, no. 2, pp. 179-197.

Özerol, G. (2013) 'Institutions of participation and environmental sustainability: A multi-level analysis from irrigation management in Harran Plain, Turkey', International Journal of the Commons vol. 7, no. 1, pp. 73-91.

Özerol, G. and Newig, J. (2008) 'Evaluating the success of public participation in water resources management - five key constituents', Water Policy, vol. 10, no. 6, pp. 639-655.Phillips, N. and Hardy, C. (2002) Discourse Analysis: Investigating Processes of Social Construction, Sage, Thousand Oaks, CA.

Scheumann, W., Baumann, V., Mueller, A.L., Mutschler, D., Steiner, S. and Walenta, T. (2011) 'Environmental impact assessment in Turkish dam planning', in A. Kibaroglu, W. Scheumann and A. Kramer (eds) Turkey's Water Policy: National Frameworks and International Cooperation, Springer, Heidelberg/Dordrecht/ London/New York.

Shepherd, A. and Bowler, C. (1997) 'Beyond the requirements: Improving public participation in EIA', Journal of Environmental Planning and Management, vol. 40, no. 6 , pp. $725-738$.

Sneddon, C. and Fox, C. (2007) 'Power, development, and institutional change: Participatory governance in the Lower Mekong Basin', World Development, vol. 35, no. 12, pp. 2161-2181.

SPO (State Planning Office) (2006) 'Ninth Development Plan (2007-2013)', SPO, Ankara.

SPO (State Planning Office) (2007a) 'Dokuzuncu Kalkınma Planı: Çevre Özel İhtisas Komisyonu Raporu (Ninth Development Plan: Report of the Specialization Commission on Environment)', SPO, Ankara. 
SPO (State Planning Office) (2007b) 'Dokuzuncu Kalkınma Planı: Toprak ve Su Kaynaklarının Kullanımı ve Yönetimi Özel 囚htisas Komisyonu Raporu (Ninth Development Plan: Report of the Specialization Commission on the Use and Management of Soil and Water Resources)', SPO, Ankara.

UNECE (United Nations Economic Commission for Europe) (1998) Convention on Access to Information, Public Participation in Decision-making and Access to Justice in Environmental Matters, UNECE, Aarhus.

Uzlu, E., Akpinar, A. and Komurcu, M.I. (2011) 'Restructuring of Turkey's electricity market and the share of hydropower energy: The case of the Eastern Black Sea Basin', Renewable Energy, vol. 36, no. 2, pp. 676-688.

Vermillion, D.L. (1997) Impacts of Irrigation Management Transfer: A Review of the Evidence, Research Report 11, International Irrigation Management Institute, Colombo. 